\title{
Histopathologic and immunohistochemical investigations of dental abscess formed in maxillofacial area
}

\author{
U.N. Yilmaz¹, R.F. Güneş Uysal' ${ }^{1}$, B. Dündar Yilmaz², M.C. Tuncer ${ }^{3}$ \\ ${ }^{1}$ Department of Oral and Maxillofacial Surgery, Faculty of Dentistry, University of Dicle, Diyarbakır, Turkey \\ 2Department of Proshetic Dentistry, Faculty of Dentistry, University of Dicle, Diyarbakır, Turkey \\ ${ }^{3}$ Department of Anatomy, Faculty of Medicine, University of Dicle, Diyarbakır, Turkey
}

[Received: 18 March 2019; Accepted: 10 April 2019]

\begin{abstract}
Background: An abscess is a pocket of pus that forms around the root of an infected tooth. In this study, we aimed to investigate the extracellular matrix proteases ADAMTS1, ADAMTS4, osteonectin, and osteopontin expressions in abscess fluid cells in jaws after implantation and prosthesis operation.

Materials and methods: In this clinical study, abscess fluids belonging to 17 patients who applied to the Department of Oral and Maxillofacial Surgery were examined histopathologically and immunohistochemically. In the histopathological examination of the abscess fluid, separation of chromatin bridges in the nuclei of neutrophil cells, pyknosis and apoptotic changes in the nucleus, degenerative change in the cytoplasm, and occasional vacuolar structures were observed.

Results: The positive reaction of ADAMTS1 was observed in fibroblast cells, plasma cells, and macrophage cells. The positive reaction of ADAMTS4 was observed in fibroblast cells, osteoclast cells, and some apoptotic leukocyte cells. Osteopontin expression in osteoclastic cells and polymorphonuclear cells was defined as positive. Osteonectin expression was positive in polymorphonuclear leukocytes and hypertrophic fibroblast cells.

Conclusions: ADAMTS1 and ADAMTS4 may induce bone destruction with its distinctive property in alveolar bone resorption, which promotes the activation of osteoclasts, which can accelerate the destruction of the extracellular matrix in the acute phase. Furthermore, osteoclastic activity increased with the increase of osteonectin and osteopontin protein expression due to inflammation in the abscess cases. (Folia Morphol 2019; 78, 4: 754-761)
\end{abstract}

Key words: tooth abscess, ADAMTS1, ADAMTS4, osteonectin, osteopontin

\section{INTRODUCTION}

The term tooth or dentoalveolar abscess is used to define the localised pus collection on the alveolar bone at the root apex. It usually occurs secondary to dental caries, trauma, deep fillings, or failed root canal treatment. After the chamber of untreated paper clay has deteriorated, the colonisation of the root canals becomes apparent with a mixture of various bacteriological agents [45]. Lymphocytes act in any immunological reaction as they are in non-immunitis. In chronic inflammation, there is a relationship between the Tlymphocytes and macrophages, with activated $T$ lymphocytes and macrophages acting on each other, causing both cells to become inflamed

Address for correspondence: Prof. M.C. Tuncer, PhD, The Chief of Anatomy Department, Dicle University, Medical School, 21280, Diyarbakır, Turkey, tel: +90 412 2488001, ext. 4539 (faculty room), fax: +90 412 2488440, e-mail: drcudi@hotmail.com 
mediators. Active lymphocytes secrete a series of chemical mediators. These are cytokines, the main stimulators of macrophages. Macrophages release interleukin-1 (IL-1) and tumour necrosis factor (TNF) containing cytokines. These also activate lymphocytes. The macrophages and T cells constantly stimulate each other in the inflammatory focus from the antigen effect from the onset [37, 52].

An abscess is a collection of localised inflammation that causes the formation of pus in the tissue. It occurs when pyogenic bacteria are placed deep into the tissue. Focal accumulation of neutrophils starts abscess formation. Immediately, a band of dilate veins forms, and fibroblastic proliferation occurs, which surrounds the abscess at the outermost limit of the abscess. After tooth extraction, alveolar bone resorption has been reported to significantly reduce the residual bone volume, and implants that are required for optimal restoration can disrupt the proper position [16, 42, 48]. This situation is more pronounced in the front of the maxilla, and palate-labial indications occur during the implant and prosthesis operation. Immediate placement of the implants in the extraction sockets can prevent this unwanted resorption [41, 43]. A disintegrin and metalloproteinase with thrombospondin motifs (ADAMTS) proteases are secreted enzymes that act on a wide variety of extracellular matrix (ECM) substrates including pro-collagen, proteoglycans, hyalectans, and cartilage oligomeric matrix protein [14, 41]. The ADAMTS1 gene is responsive to inflammation that is not expressed in normal tissues, but it is induced by lipopolysaccharide stimulation [19]. The major enzymes ADAMTS4 and ADAMTS5 are involved in the degradation of the main proteoglycan agonist in articular cartilage and have been shown to be the target for therapeutic inhibition leading to the development of osteoarthritis [47].

Osteopontin (OPN) is a secreted phosphoprotein with various roles in the immune response. It is made by $T$ cells and macrophages and binds to a series of integrins as an intact protein or as proteolytically cleaved fragments [14]. Moreover, OPN is expressed in various cell types and tissues, such as preosteoblasts, osteoblasts, osteocytes [6], fibroblasts [49], dendritic cells, macrophages, and T cells [22]. Osteonectin (ON) is a glycoprotein synthesised by the cells of an osteoblastic lineage, which is abundantly expressed in bones undergoing active remodelling. It binds hydroxyapatite, calcium, and type I collagen and inhibits

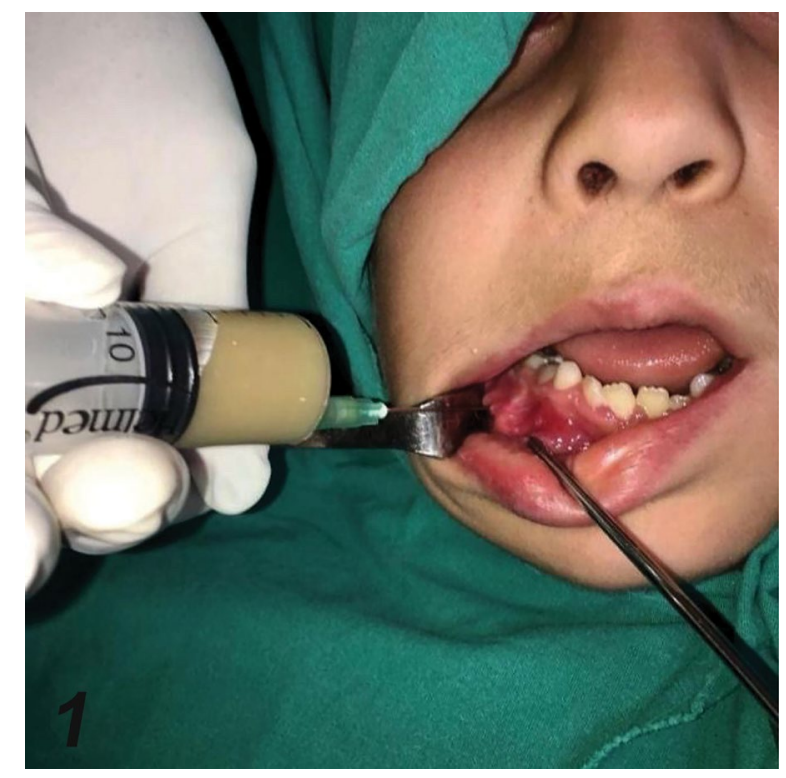

Figure 1. Fine-needle aspiration for abscess fluid formed in the submandibular area.

mineralisation in vitro [18]. Classically, ON has been used to follow the progression of in vivo and in vitro osteoblast cytodifferentiation $[2,20,24]$.

In this study, we aimed to investigate the ECM proteases ADAMTS1, ADAMTS4, ON and OPN expressions in abscess fluid cells in jaws after implantation and prosthesis operation.

\section{MATERIALS AND METHODS}

\section{Patient follow-up}

In this clinical study, abscess fluids belonging to 17 patients who applied to the Department of Oral and Maxillofacial Surgery were examined histopathologically and immunohistochemically. This study was registered as a prospective clinical trial with the Dental Faculty Hospital Trial Registry. Informed consent was obtained from the patients before enrolment in the clinical evaluation. A written informed consent form was obtained from the parents of children younger than 18 years old.

\section{Fine-needle aspiration cytology}

Fine-needle aspiration was performed with a 20-25 gauge needle (Fig. 1). The abscess fluid that we obtained was conserved at $+4^{\circ} \mathrm{C}$. Then, the materials were sent to the histology laboratory for routine histological procedures. The abscess fluid was subjected to high-speed centrifugation, the supernatant was discarded, and $10 \%(\mathrm{v} / \mathrm{v})$ neutral formalin was added 
(pellet to formalin volume ratio, 1:3). After $2 \mathrm{~h}$ of fixation, the clear bright supernatant was discarded, and the tube was inverted on filter paper to allow excess fluid to drain. The pellet was then placed on filter paper using a spatula, and eosin stain solution was added using a Pasteur pipette. After the cell aggregate developed a red colour, it was wrapped in filter paper and placed in a cassette, which was then stored in a fixation box for tissue processing. The cells were examined using Harris haematoxylin and eosin (H\&E) staining. The abscess fluid was also immunostained and examined under Olympus BH-2 light microscopy.

\section{Haematoxylin and eosin staining procedure}

1. Deparaffinize sections, two changes of xylene, 10 min each.

2. Re-hydrate in two changes of absolute alcohol, 5 min each.

3. $95 \%$ alcohol for $2 \mathrm{~min}$ and $70 \%$ alcohol for $2 \mathrm{~min}$.

4. Wash briefly in distilled water.

5. Stain in Harris haematoxylin solution for $8 \mathrm{~min}$.

6. Wash in running tap water for 5 min.

7. Differentiate in $1 \%$ acid alcohol for $30 \mathrm{~s}$.

8. Wash running tap water for $1 \mathrm{~min}$.

9. Bluing in $0.2 \%$ ammonia water or saturated lithium carbonate solution for $30 \mathrm{~s}$ to $1 \mathrm{~min}$.

10. Wash in running tap water for $5 \mathrm{~min}$.

11. Rinse in $95 \%$ alcohol, 10 dips.

12. Counterstain in eosin-phloxine solution for $30 \mathrm{~s}$ to $1 \mathrm{~min}$.

13. Dehydrate through $95 \%$ alcohol, two changes of absolute alcohol, 5 min each.

14. Clear in two changes of xylene, 5 min each.

15. Mount with xylene based mounting medium.

\section{Immunohistochemical staining}

Sections of abscess fluid cells were brought to distilled water and washed in $3 \times 5$ min phosphate buffered saline (PBS; catalogue number 10010023, Thermo Fischer Scientific Fremont, CA, USA). Antigen retrieval was done in a microwave (Bosch ${ }^{\circledR}, 700$ watt) for $3 \mathrm{~min}$ at $90^{\circ} \mathrm{C}$. They were subjected to a heating process in a microwave oven at 700 watts in a citrate buffer $(\mathrm{pH} 6)$ solution for proteolysis. Sections were washed in $3 \times 5$ min PBS and incubated with hydrogen peroxide [K-40677109,64271 hydrogen peroxide $\left(\mathrm{H}_{2} \mathrm{O}_{2}\right)$ Dortmund, Germany, Merck] $\left(3 \mathrm{~mL} 30 \% \mathrm{H}_{2} \mathrm{O}_{2}\right.$ $+27 \mathrm{~mL}$ methanol) for $20 \mathrm{~min}$. Sections were washed in $3 \times 5$ min PBS and blocked with ultra $v$ block (lot: PHL150128, Thermo Fischer, Fremont, CA, USA) for $8 \mathrm{~min}$. After draining, the primary antibodies were directly applied to the sections, namely, ADAMTS1 monoclonal antibody 1:100, ADAMTS4 monoclonal antibody 1:100, ON monoclonal antibody 1:100, and OPN monoclonal antibody 1:100. Sections were incubated and left overnight at $4^{\circ} \mathrm{C}$. Sections were washed in $3 \times 5$ min PBS and then incubated with biotinylated secondary antibody (lot: PHL150128, Thermo Fischer, Fremont, CA, USA) for $14 \mathrm{~min}$. After washing with $\mathrm{PBS}$, streptavidin peroxidase (lot: PHL150128, Thermo Fischer, Fremont, CA, USA) was applied to the sections for $15 \mathrm{~min}$. The sections were washed in $3 \times 5$ min PBS, and DAB (lot: HD36221, Thermo Fischer, Fremont, CA, USA) was applied to sections for up to $10 \mathrm{~min}$. Slides showing a reaction were stopped in PBS. Counterstaining was done with Harris's haematoxylin for $45 \mathrm{~s}$, dehydrated through ascending alcohol and cleared in xylene (product number: HHS32 Sigma, haematoxylin solution, Harris modified, Sigma-Aldrich, Saint Louis, MO, USA). Slides were mounted with Entellan ${ }^{\circledR}$ (lot: 107961, Sigma-Aldrich, St. Louis, MO, USA) and examined under Olympus BH-2 light microscopy.

\section{Semi-quantitative score of histopathologic parameters}

Semi-quantitative score was determined by examining chromatin bridges breakage in nucleus of neutrophil cells, apoptotic changes in nucleus of lekocyte cells, vacuolar structures in leukocyte cells, ADAMTS1 expression in fibroblast cells, ADAMTS4 expression in fibroblast cells, OPN expression in polimorph nucleus of leukocyte cells, and ON expression in osteoclast cells in the histological sections of abscess fluid. Microscopic examination of these parameters was performed in 15 different fields and counting 10 cells in each area (Tables 1 and 2).

\section{Statistical analysis}

Statistical analysis was performed using SPSS 21.0 for Windows statistical package. Statistical analysis was performed with mean \pm standard deviation and categorical variables were presented with number and per cent. Chi-square test was used for comparison of qualitative variables between groups. Hypotheses were biased. $\mathrm{P} \leq 0.05$, a statistically significant result was considered. 
Table 1. Valid and cumulative per cent of histopathological parameters

\begin{tabular}{lcccc}
\hline Histopathological parameters & Patient $(\mathbf{n})$ & Per cent & Valid per cent & Cumulative per cent \\
\hline Chromatin bridges breakage in nucleus of neutrophil cells & 17 & 14.3 & 14.3 & 14.3 \\
Apoptotic changes in nucleus of leukocyte cells & 17 & 14.3 & 14.3 & 28.6 \\
Vacuolar structures in leukocyte cells & 17 & 14.3 & 14.3 & 42.9 \\
ADAMTS1 expression in fibroblast cells & 17 & 14.3 & 14.3 & 57.1 \\
ADAMTS4 expression in fibroblast cells & 17 & 14.3 & 14.3 & 71.4 \\
Osteopontin expression in polymorph nucleus of leukocyte cells & 17 & 14.3 & 14.3 & 85.7 \\
Osteonectin expression in osteoclast cells & 17 & 14.3 & 14.3 & 100.0 \\
Total & 119 & 100.0 & 100.0 & \\
\hline
\end{tabular}

Table 2. Semi-quantitative score of histopathological parameters in patients

\begin{tabular}{lcccccccc}
\hline Scores (0-4) & \multicolumn{7}{c}{ Parameters - N (\%) } \\
\cline { 2 - 8 } in patients & $\begin{array}{c}\text { Chromatin } \\
\text { bridges } \\
\text { breakage in } \\
\text { nucleus of } \\
\text { neutrophil } \\
\text { cells }\end{array}$ & $\begin{array}{c}\text { Apoptotic } \\
\text { changes in } \\
\text { nucleus of } \\
\text { leukocyte } \\
\text { cells }\end{array}$ & $\begin{array}{c}\text { Vacuolar } \\
\text { structures } \\
\text { in leukocyte } \\
\text { cells }\end{array}$ & $\begin{array}{c}\text { ADAMTS1 } \\
\text { expression } \\
\text { in fibroblast } \\
\text { cells }\end{array}$ & $\begin{array}{c}\text { ADAMTS4 } \\
\text { expression } \\
\text { in fibroblast } \\
\text { cells }\end{array}$ & $\begin{array}{c}\text { Osteopontin } \\
\text { expression } \\
\text { in polymorph } \\
\text { nucleus of } \\
\text { leukocyte } \\
\text { cells }\end{array}$ & $\begin{array}{c}\text { Osteonectin } \\
\text { expression }\end{array}$ & $\begin{array}{c}\text { Total } \\
\text { in osteoclast } \\
\text { cells }\end{array}$ \\
\hline $0-2$ & $0(0 \%)$ & $2(20.0 \%)$ & $2(20.0 \%)$ & $2(20.0 \%)$ & $0(0 \%)$ & $3(30.0 \%)$ & $1(10.0 \%)$ & $10(100 \%)$ \\
3 & $8(12.7 \%)$ & $10(15.9 \%)$ & $10(15.9 \%)$ & $11(17.5 \%)$ & $5(7.9 \%)$ & $10(15.9 \%)$ & $9(14.3 \%)$ & $63(100 \%)$ \\
4 & $9(19.6 \%)$ & $5(10.9 \%)$ & $5(10.9 \%)$ & $4(8.7 \%)$ & $12(26.1 \%)$ & $4(8.7 \%)$ & $7(15.2 \%)$ & $46(100 \%)$ \\
Total-Count (\%) & $17(14.3 \%)$ & $17(14.3 \%)$ & $17(14.3 \%)$ & $17(14.3 \%)$ & $17(14.3 \%)$ & $17(14.3 \%)$ & $17(14.3 \%)$ & $119(100 \%)$ \\
\hline
\end{tabular}

The quantification of all parameters: 0 - no change, 1 - too weak, 2 - weak, 3 - middle, 4 - strong. Scoring was determined by examining histological parameters in 15 different regions within the microscope field, and 10 cells counted in each area

\section{RESULTS}

\section{Statistical findings}

Statistical results of histopathological parameters are given in Tables 1 and 2 in detail.

\section{Histological findings}

In the histopathological examination of the abscess fluid, we observed separation of chromatin bridges in the nuclei of neutrophil cells, pyknosis and apoptotic changes in the nucleus, degenerative change in the cytoplasm, and occasional vacuolar structures. The nucleus size in lymphocytes is normally close to that of the cytoplasm, while nuclear shrinkage and cytoplasm are larger due to infection (Fig. 2).

\section{Immunohistochemical findings}

A positive reaction of ADAMTS1 was observed in fibroblast cells, plasma cells, and macrophage cells (Fig. 3). In addition, a positive reaction of ADAMTS4 was observed in fibroblast cells, osteoclast cells, and some apoptotic leukocyte cells (Fig. 4). The expression of OPN in osteoclastic cells and polymorphonuclear cells was defined as positive (Fig. 5). The expression of ON was positive in polymorphonuclear leukocytes and hypertrophic fibroblast cells. In the periapical abscess, oedema and hyperaemia occur due to the infiltration of periodontal membrane inflammation cells in the root tip. Bone resorption occurs with inflammation in the mouth (Fig. 6).

\section{DISCUSSION}

In this clinical study, we examined immunohistochemical expressions of ADAMTS1, ADAMTS4, ON, and OPN proteins in abscess fluid cells formed during surgical procedures applied to implant or prosthetic patients. In the literature review, we did not find a scientific study showing the relationship between the expressions of these proteins and abscess fluid cells. Immunohistochemical cross sections of these proteins in the abscess fluid were shown in detail (Figs. 2-6).

The formation of periradicular lesions involves inflammatory cell infiltration, necrosis, abscess formation, apical periodontal ECM degradation, and resorption of root and alveolar bone as the result 


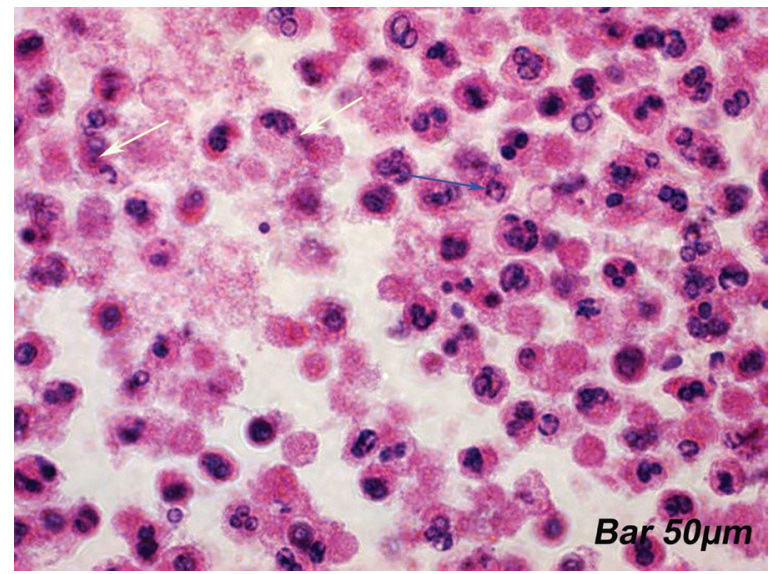

Figure 2. Haematoxylin-eosin staining. Separation of chromatin bridges in the nuclei of neutrophil cells (white arrows) and degenerative changes and apoptosis in some leukocyte cells (blue arrow). Scale bar $=50 \mu \mathrm{m}$.

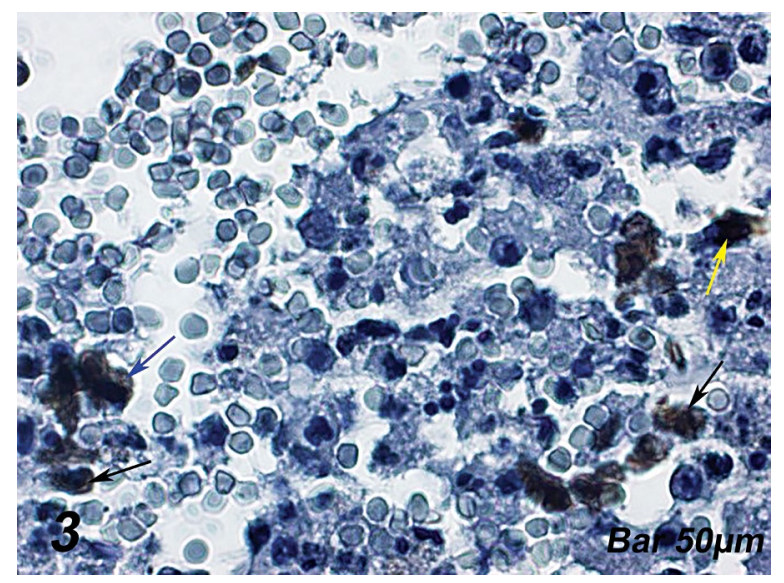

Figure 3. ADAMTS1 immunostaining. Positive expression of ADAMTS1 in fibroblast cells (yellow arrow), plasma cells (black arrow), and macrophage cells (blue arrow). Scale bar $=50 \mu \mathrm{m}$.

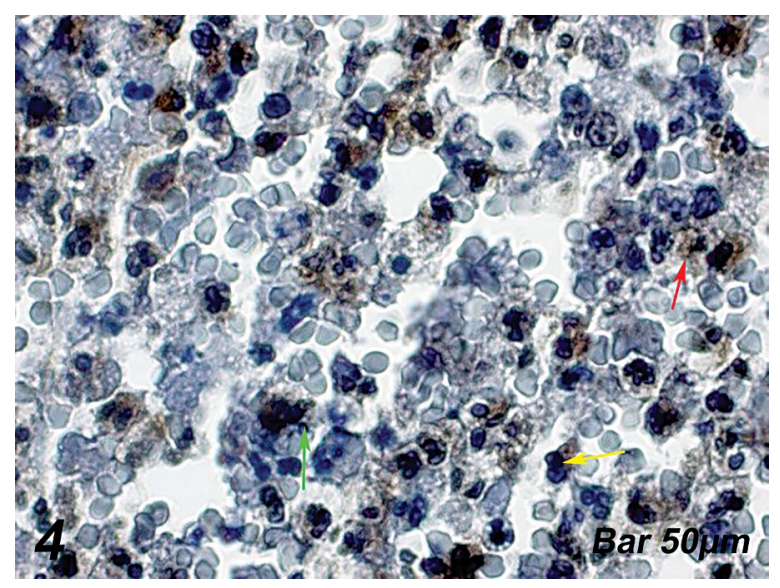

Figure 4. ADAMTS4 immunostaining. Positive expression of ADAMTS4 in fibroblast cells (yellow arrow), osteoclast cells (green arrow), and some apoptotic leukocyte cells (red arrow). Scale bar $=50 \mu \mathrm{m}$.

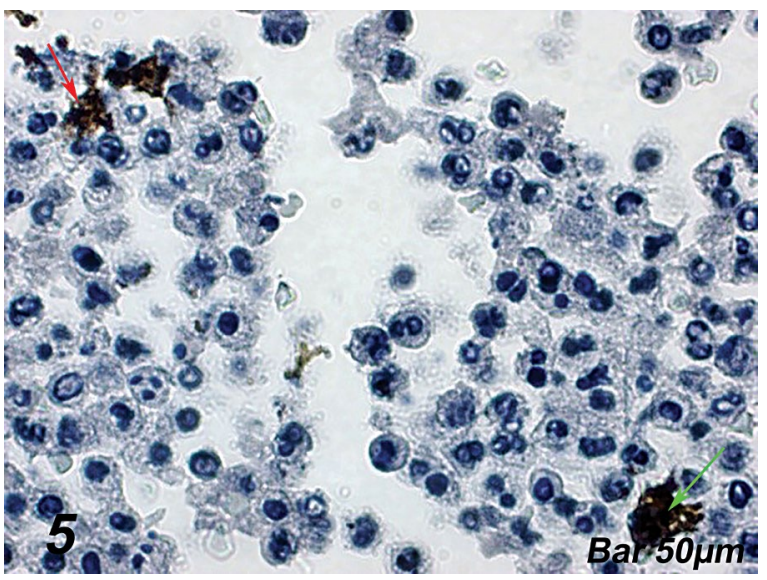

Figure 5. Osteopontin (OPN) immunostaining. Positive OPN expression in osteoclastic cells (green arrow) and degenerative polymorphonuclear cells (red arrow). Scale bar $=50 \mu \mathrm{m}$.

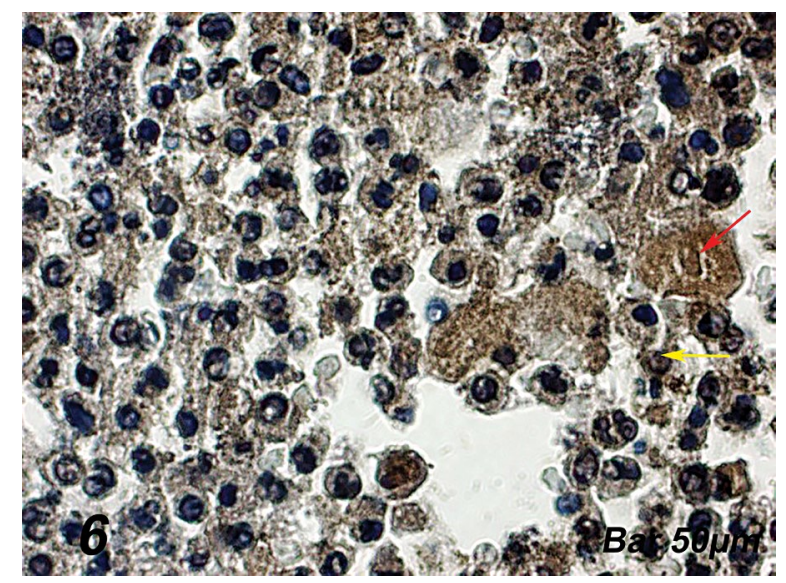

Figure 6. Osteonectin (ON) immunostaining. Positive ON expression in polymorphonuclear leukocytes (red arrow) and hypertrophic fibroblast cells (yellow arrow). Scale bar $=50 \mu \mathrm{m}$.

of continuous stimulation from bacteria in the root canal [50]. Clinical practices have indicated that periodontal, endodontic, and implant-phase infection is an important predictor of implant development and reduces the chances for successful implant placement $[3,17,29,34,35]$. The goal of implant therapy is to improve the quality of life of patients by allowing the removal of removable dentures and reducing the burden on sensitive soft tissues. Periapical implant lesions show a pathological osteolysis area at the apex of the osseointegrated implant [8, 30-32]. Contamination of implants may be explained by the presence of necrotic and traumatised bone tissue and/or impaired host defence mechanisms. The detection of enzymes from polymorphonuclear granulocytes (PMN) at high concentrations in peri-implanted regions may indicate 
increased PMN cell activity [4]. A high number of PMN cells associated with a significant amount of mucosal inflammation around the implants have been identified [36]. A few histopathological and immunohistochemical analyses of the peri-implantitis indications of the tissues surrounding the implants, namely clinical signs of inflammation, revealed advanced bone loss and the presence of large inflammatory cell infiltrates $[9,12,21,33]$. Esposito et al. [9] analysed the properties of soft tissues surrounding implants that fail immunohistochemically. They reported that a marginal portion of the specimens was characterised by intense inflammation and immunological responses. Demircan et al. [7] reported that the ADAMTS enzyme levels and activities should be illuminated at both the protein and mRNA levels of tissue inhibitor proteins in bone formation. Moreover, ADAMTS8 is released from neutrophils or macrophages during the acute phase of lesion formation and promotes the formation and activation of osteoclasts [11]. In addition, ADAMTS1 and ADAMTS4 may play an important role in aortic inflammation. Inflammatory cells such as macrophages play critical roles in the progression of aortic aneurysms by producing proinflammatory cytokines and proteolytic enzymes [44]. The ADAMTS1 and ADAMTS4 proteins may support tissue destruction and disease formation by various mechanisms. Mimata et al. [26] found that ADAMTS4 expression is upregulated in fibroblast-like synoviocytes in patients with IL-6 rheumatoid arthritis. It has been indicated that IL-6 it may induce ADAMTS4 expression from fibroblast-like synoviocytes in cartilage destruction in rheumatoid arthritis. In our study of ADAMTS1 and ADAMTS4 immunohistochemical analysis, fibroblast cells, macrophage cells, and some apoptotic leucocytes as well as ADAMTS1 and ADAMTS4 expressions in osteoclast cells were positive. It was thought that ADAMTS1 and ADAMTS4 may be predictive of the modulation of inflammation and bone metabolism as well as tissue damage, including alveolar bone resorption and the development of gingival lesions in the early phase after prosthetic and implant operations. Several recent studies have demonstrated the effect of cytokines, such as IL-beta, TNF-alpha, and transforming growth factor-beta on the expression of ADAMTS4 and ADAMTS5 in fibroblast-like synoviocytes $[13,26,53]$.

Moreover, OPN is induced in macrophages by several inflammatory cytokines including TNF-alpha, IL-1p, interferon-gamma (IFN-gamma), and IL-6. Other factors, such as angiotensin-Il, oxidised low-density lipoprotein, and phorbol-ester, are inducers of OPN $[5,27,28]$. In addition, OPN changes chronic inflammatory responses. Chronic inflammation is characterised by the persistence of injury to macrophages and disease sites [22]. During cell-mediated immune responses against bacterial and viral pathogens, OPN plays a pivotal role in T cell and macrophage responses [1]. Moreover, OPN has been shown to downregulate IL-10. It is thought to increase bone destruction associated with endodontic infections [39].

Additionally, ON is a non-collagenous protein of the bone matrix that is quite ubiquitously expressed $[25,51]$. Moreover, ON has also been observed in bovine odontoblasts $[10,15]$ and in odontoblasts and predentin in human prenatal and postnatal samples [38]. This extracellular distribution may be related to the specific polarised tissue organisation where only the odontoblast process is included in the mineralised matrix [40]. On the other hand, the cellular processes of ON-producing odontoblasts are in contact with mechanical stresses, heat shocks, and cariogenic bacteria products $[23,46]$. Our data also suggest that ON expression increased due to bone tissue damage.

Despite the results, there are a few limitations. When the histopathological parameters were evaluated statistically in a total of 17 patients in according to semi-quantitative score, the remarkable results are as follows:

- no patient was found to break the chromatin bridges in the nucleus of neutrophil cells. But, this deformity was prominent in 9 patients;

- apoptotic changes in leukocyte cell nuclei, vacuolar structures in leukocyte cells, and osteopontin expression in polymorph nucleus of leukocyte cells were moderate in ten patients;

- ADAMTS1 expression in fibroblast cells was prominent in eleven patients;

- ADAMTS4 expression in fibroblast cells was prominent in twelve patients;

- osteonectin expression in osteoclast cells was moderate in 9 patients.

When these parameters were evaluated cumulatively; remarkable protein expression results are as follows:

- osteopontin expression in osteoclast cells was seen in all patients;

- osteopontin expression was detected in polymorphous nuclei of leukocyte cells in $85.7 \%$ of patients; 
- ADAMTS4 expression was detected in fibroblast cells in $71.4 \%$ of patients;

- ADAMTS1 expression was detected in fibroblast cells in $57.1 \%$ of patients.

\section{CONCLUSIONS}

We consider that ADAMTS1 and ADAMTS4 may induce bone destruction with their distinctive property of alveolar bone resorption, which promotes the activation of osteoclasts, which can accelerate the destruction of ECM in the acute phase. In cases of acute and chronic abscesses, ON and OPN protein increases were observed in osteocyte cells due to maxilla and mandibular bone tissue damage. Bone destruction was also thought to be induced due to a marked increase in osteoclast activity.

\section{REFERENCES}

1. Ashkar S, Weber GF, Panoutsakopoulou V, et al. Eta-1 (osteopontin): an early component of type-1 (cell-mediated) immunity. Science. 2000; 287(5454): 860-864, doi: 10.1126/science.287.5454.860, indexed in Pubmed: 10657301.

2. Aubin JE, Liu F, Malaval L, et al. Osteoblast differentiation. Bone. 1995; 17(Suppl 2): 77S-83S.

3. Ayangco L, Sheridan PJ. Development and treatment of retrograde peri-implantitis involving a site with a history of failed endodontic and apicoectomy procedures: a series of reports. Int J Oral Maxillofac Implants. 2001; 16(3): 412-417, indexed in Pubmed: 11432661.

4. Behneke A, Behneke N, d'Hoedt B. The longitudinal clinical effectiveness of ITI solid-screw implants in partially edentulous patients: a 5-year follow-up report. Int J Oral Maxillofac Implants. 2000; 15(5): 633-645, indexed in Pubmed: 11055130.

5. Bruemmer D, Collins AR, Noh G, et al. Angiotensin Il-accelerated atherosclerosis and aneurysm formation is attenuated in osteopontin-deficient mice. J Clin Invest. 2003; 112(9): 1318-1331, doi: 10.1172/JCl18141, indexed in Pubmed: 14597759.

6. Chen Q, Shou P, Zhang L, et al. An osteopontin-integrin interaction plays a critical role in directing adipogenesis and osteogenesis by mesenchymal stem cells. Stem Cells. 2014; 32(2): 327-337, doi: 10.1002/stem.1567, indexed in Pubmed: 24123709.

7. Demircan K, Hirohata $S$, Nishida K, et al. ADAMTS-9 is synergistically induced by interleukin-1 beta and tumor necrosis factor alpha in OUMS-27 chondrosarcoma cells and in human chondrocytes. Arthritis Rheum. 2005; 52(5): 1451-1460, doi: 10.1002/art.21010, indexed in Pubmed: 15880812.

8. Esposito M, Thomsen P, Ericson LE, et al. Histopathologic observations on early oral implant failures. Int J Oral Maxillofac Implants. 1999; 14(6): 798-810, indexed in Pubmed: 10612916.

9. Esposito M, Thomsen P, Mölne J, et al. Immunohistochemistry of soft tissues surrounding late failures of Brånemark implants. Clin Oral Implants Res. 1997; 8(5): 352-366, indexed in Pubmed: 9612140.

10. Fujisawa R, Kuboki Y. Changes in levels of osteonectin in bovine dentine during tooth development. Arch Oral Biol.
1989; 34(2): 89-92, doi: 10.1016/0003-9969(89)90131-3, indexed in Pubmed: 2783051.

11. Gómez-Gaviro M, Domínguez-Luis M, Canchado J, et al. Expression and regulation of the metalloproteinase ADAM-8 during human neutrophil pathophysiological activation and its catalytic activity on L-selectin shedding. J Immunol. 2007; 178(12): 8053-8063, doi: 10.4049/ jimmunol.178.12.8053, indexed in Pubmed: 17548643.

12. Gualini F, Berglundh T. Immunohistochemical characteristics of inflammatory lesions at implants. J Clin Periodontol. 2003; 30(1): 14-18, doi: 10.1034/j.1600051x.2003.300103.x, indexed in Pubmed: 12702106.

13. Imada K, Tsuchida A, Ogawa K, et al. Anti-arthritic actions of $\beta$-cryptoxanthin against the degradation of articular cartilage in vivo and in vitro. Biochem Biophys Res Commun. 2016; 476(4): 352-358, doi: 10.1016/j.bbrc.2016.05.126, indexed in Pubmed: 27240953.

14. Jones GC, Riley GP. ADAMTS proteinases: a multi-domain, multi-functional family with roles in extracellular matrix turnover and arthritis. Arthritis Res Ther. 2005; 7(4): 160-169, doi: 10.1186/ar1783, indexed in Pubmed: 15987500.

15. Jontell $M$, Linde $A$. Non-collagenous proteins of predentine from dentinogenically active bovine teeth. Biochem J. 1983; 214(3): 769-776, doi: 10.1042/bj2140769, indexed in Pubmed: 6626156

16. Kan JY, Shiotsu G, Rungcharassaeng K, et al. Maintaining and attenuating periodontal tissues for aesthetic implant placement. J Oral Implantol. 2000; 26(1): 35-41, doi: 10.1563/1548-1336(2000)026<0035:MAAPTF>2.3. CO;2, indexed in Pubmed: 11831300.

17. Karoussis IK, Salvi GE, Heitz-Mayfield UA, et al. Long-term implant prognosis in patients with and without a history of chronic periodontitis: a 10-year prospective cohort study of the ITI Dental Implant System. Clin Oral Implants Res. 2003; 14(3): 329-339, indexed in Pubmed: 12755783.

18. Kelm RJ, Swords NA, Orfeo T, et al. Osteonectin in matrix remodeling: A plasminogen-osteonectin-collagen complex . J Biol Chem. 1994 ; 269(48): 30147-30153.

19. Kuno K, Kanada N, Nakashima E, et al. Molecular cloning of a gene encoding a new type of metalloproteinase-disintegrin family protein with thrombospondin motifs as an inflammation associated gene. J Biol Chem. 1997; 272(1): 556-562, doi: 10.1074/jbc.272.1.556, indexed in Pubmed: 8995297.

20. Lian JB, Stein GS, Bortell R, et al. Phenotype suppression: a postulated molecular mechanism for mediating the relationship of proliferation and differentiation by Fos/Jun interactions at AP-1 sites in steroid responsive promoter elements of tissue-specific genes. J Cell Biochem. 1991; 45(1): 9-14, doi: 10.1002/jcb.240450106, indexed in Pubmed: 1900844

21. Lindhe J, Berglundh T, Ericsson I, et al. Experimental breakdown of peri-implant and periodontal tissues. A study in the beagle dog. Clinical Oral Implants Res. 1992; 3(1): 9-16, doi: 10.1034/j.1600-0501.1992.030102.x.

22. Lund SA, Giachelli CM, Scatena M. The role of osteopontin in inflammatory processes. J Cell Commun Signal. 2009; 3(3-4): 311-322, doi: 10.1007/s12079-009-0068-0, indexed in Pubmed: 19798593.

23. Magloire $H$, Bouvier $M$, Joffre A. Odontoblast response under carious lesions. Proc Finn Dent Soc. 1992; 88 (Suppl 1): 257-274, indexed in Pubmed: 1508881.

24. Malaval L, Modrowski D, Gupta AK, et al. Cellular expression of bone-related proteins during in vitro osteogenesis in rat bone marrow stromal cell cultures. J Cell Physiol. 1994; 158(3): 555-572, doi: 10.1002/jcp.1041580322, indexed in Pubmed: 8126078. 
25. McVey JH, Nomura S, Kelly P, et al. Characterization of the mouse SPARC/osteonectin gene. Intron/exon organization and an unusual promoter region. J Biol Chem. 1988; 263(23): 11111-11116, indexed in Pubmed: 3165375.

26. Mimata $Y$, Kamataki A, Oikawa $S$, et al. Interleukin-6 upregulates expression of ADAMTS-4 in fibroblast-like synoviocytes from patients with rheumatoid arthritis. Int J Rheum Dis. 2012; 15(1): 36-44, doi: 10.1111/j.1756185X.2011.01656.x, indexed in Pubmed: 22324945.

27. Nakamachi T, Nomiyama T, Gizard F, et al. PPARalpha agonists suppress osteopontin expression in macrophages and decrease plasma levels in patients with type 2 diabetes. Diabetes. 2007; 56(6): 1662-1670, doi: 10.2337/db061177, indexed in Pubmed: 17360982.

28. Ogawa D, Stone JF, Takata Y, et al. Liver $x$ receptor agonists inhibit cytokine-induced osteopontin expression in macrophages through interference with activator protein-1 signaling pathways. Circ Res. 2005; 96(7): e59-e67, doi: 10.1161/01.RES.0000163630.86796.17, indexed in Pubmed: 15790955.

29. Oh TJ, Yoon J, Wang HL. Management of the implant periapical lesion: a case report. Implant Dent. 2003; 12(1): 41-46, indexed in Pubmed: 12704955.

30. Piattelli A, Scarano A, Balleri $P$, et al. Clinical and histologic evaluation of an active "implant periapical lesion": a case report. Int J Oral Maxillofac Implants. 1998; 13(5): 713-716, indexed in Pubmed: 9796159.

31. Piattelli A, Scarano A, Piattelli M, et al. Implant periapical lesions: clinical, histologic, and histochemical aspects. A case report. Int J Periodontics Restorative Dent. 1998; 18(2): 181-187, indexed in Pubmed: 9663096.

32. Piattelli A, Scarano A, Piattelli M. Abscess formation around the apex of a maxillary root form implant: clinical and microscopical aspects. A case report. J Periodontol. 1995; 66(10): 899-903, doi: 10.1902/jop.1995.66.10.899, indexed in Pubmed: 8537875.

33. Piattelli A, Scarano A, Piattelli M. Histologic observations on 230 retrieved dental implants: 8 years' experience (1989-1996). J Periodontol. 1998; 69(2): 178-184, doi: 10.1902/ /jop.1998.69.2.178, indexed in Pubmed: 9526917.

34. Polizzi G, Grunder U, Goené R, et al. Immediate and delayed implant placement into extraction sockets: a 5-year report. Clin Implant Dent Relat Res. 2000; 2(2): 93-99, indexed in Pubmed: 11359269.

35. Pompa G, Saccucci M, Di Carlo G, et al. Survival of dental implants in patients with oral cancer treated by surgery and radiotherapy: a retrospective study. BMC Oral Health. 2015; 15: 5, doi: 10.1186/1472-6831-15-5, indexed in Pubmed: 25599761.

36. Rams TE, Roberts TW, Tatum $\mathrm{H}$, et al. The subgingival microbial flora associated with human dental implants. J Prosthet Dent. 1984; 51(4): 529-534, doi: 10.1016/00223913(84)90309-3, indexed in Pubmed: 6374110.

37. Rautenschlein S, Subramanian A, Sharma JM. Bioactivities of a tumour necrosis-like factor released by chicken macrophages. Dev Comp Immunol. 1999; 23(7-8): 629-640, doi: 10.1016/s0145-305x(99)00043-9, indexed in Pubmed: 10579391.

38. Reichert T, Störkel S, Becker K, et al. The role of osteonectin in human tooth development: an immunohistological study. Calcif Tissue Int. 1992; 50(5): 468-472, doi: 10.1007/bf00296779, indexed in Pubmed: 1596782.
39. Rittling SR, Zetterberg C, Yagiz K, et al. Protective role of osteopontin in endodontic infection. Immunology. 2010; 129(1): 105-114, doi: 10.1111/j.1365-2567.2009.03159.x, indexed in Pubmed: 19824920.

40. Ruch JV, Lesot $H$, Bègue-Kirn C. Odontoblast differentiation. Int J Dev Biol. 1995; 39(1): 51-68.

41. Salter RC, Ashlin TG, Kwan APL, et al. ADAMTS proteases: key roles in atherosclerosis? J Mol Med (Berl). 2010; 88(12): 1203-1211, doi: 10.1007/s00109-010-0654-x, indexed in Pubmed: 20652528.

42. Schnutenhaus S, Doering I, Dreyhaupt J, et al. Alveolar ridge preservation with a collagen material: a randomized controlled trial. J Periodontal Implant Sci. 2018; 48(4): 236-250, doi: 10.5051/jpis.2018.48.4.236, indexed in Pubmed: 30202607.

43. Schropp L, Kostopoulos L, Wenzel A. Bone healing following immediate versus delayed placement of titanium implants into extraction sockets: a prospective clinical study. Int J Oral Maxillofac Implants. 2003; 18(2): 189-199, indexed in Pubmed: 12705296.

44. Shimizu K, Mitchell RN, Libby P. Inflammation and cellular immune responses in abdominal aortic aneurysms. Arterioscler Thromb Vasc Biol. 2006; 26(5): 987-994, doi: 10.1161/01.ATV.0000214999.12921.4f, indexed in Pubmed: 16497993.

45. Shweta, Prakash SK. Dental abscess: A microbiological review. Dent Res J (Isfahan). 2013; 10(5): 585-591, indexed in Pubmed: 24348613.

46. Smith AJ, Cassidy N, Perry H, et al. Reactionary dentinogenesis. Int J Dev Biol. 1995; 39(1): 273-280, indexed in Pubmed: 7626417.

47. Troeberg L, Nagase H. Proteases involved in cartilage matrix degradation in osteoarthritis. Biochim Biophys Acta. 2012; 1824(1): 133-145, doi: 10.1016/j.bbapap.2011.06.020, indexed in Pubmed: 21777704.

48. Werbitt MJ, Goldberg PV. The immediate implant: bone preservation and bone regeneration. Int J Periodontics Restorative Dent. 1992; 12(3): 206-217.

49. Xie Z, Singh $M$, Siwik DA, et al. Osteopontin inhibits interleukin-1 beta-stimulated increases in matrix metalloproteinase activity in adult rat cardiac fibroblasts: role of protein kinase C-zeta. J Biol Chem. 2003; 278(49): 48546-48552, doi: 10.1074/jbc.M302727200, indexed in Pubmed: 14500723.

50. Yamasaki M, Kumazawa M, Kohsaka T, et al. Pulpal and periapical tissue reactions after experimental pulpal exposure in rats. J Endod. 1994; 20(1): 13-17, indexed in Pubmed: 8182380.

51. Yan Q, Sage EH. SPARC, a matricellular glycoprotein with important biological functions. J Histochem Cytochem. 1999; 47(12): 1495-1506, doi: 10.1177/002215549904 701201, indexed in Pubmed: 10567433.

52. Yan $Y$, Liu F, Kou $X$, et al. T cells are required for orthodontic tooth movement. J Dent Res. 2015; 94(10): 1463-1470, doi: 10.1177/0022034515595003, indexed in Pubmed: 26187644.

53. Yaykasli KO, Hatipoglu OF, Yaykasli E, et al. Leptin induces ADAMTS-4, ADAMTS-5, and ADAMTS- 9 genes expression by mitogen-activated protein kinases and NF-KB signaling pathways in human chondrocytes. Cell Biol Int. 2015; 39(1): 104-112, doi: $10.1002 /$ cbin. 10336 , indexed in Pubmed: 25045124. 